\title{
Biofuel Energy Production as Catalyst for Sustainable Agriculture in Nigeria
}

\author{
Luke Onyekakeyah $^{\mathrm{a} *}$
}

\begin{abstract}
Two factors underlie the quest for biofuel energy production in Nigeria. First is the availability of vast arable agricultural land that is lying waste and largely uncultivated. The oil boom of the mid 70s upturned the country's economy from being predominantly agrarian economy to crude oil based diseconomy. The result is the shift to oil as a major source of foreign revenue. Consequently, the share of agricultural production in total exports plummeted from over 70 per cent in 1960 to less than 2 per cent today. The abandonment of agriculture has disorientated the economy, which is far from being developed. Second is the energy crisis that hit the economy due to the mismanagement of the crude oil revenue earnings and lack of appropriate energy policy framework. The collapse of the electricity sub-sector and the prohibitive price of petrol and other domestic cooking gas and kerosene forced the authorities to seek alternative sources of cheap fuel. The result was the decision by government to give impetus to biofuel production as one alternative energy source. The development of biofuel would inevitably boost agricultural production of the main cash crops needed as raw materials in industrial biofuel production. How to rekindle interest in agriculture has for decades remained a daunting problem to government.The objective of this paper is to review the policy framework and actions already put forward for biofuel production and asses the implications of such developments on agricultural production. This is with a view to ascertaining to what extent the introduction of biofuel into the energy mix would help to revamp the dwindled agricultural economy. In making this assessment, we sought and obtained relevant information from published materials relating to the issue of concern. These were analyzed in the light of the prevailing circumstances in the country's agricultural sector. Based on the information gathered and analyzed, we found out that embarking on biofuel as a source of energy would not only rekindle interest in farming but would boost commercial agricultural production of a variety of crops. Essentially, biofuel energy has the capacity to catalyze renewed interest in sustainable agriculture in the country. The study is significant as a source of information for policy makers in planning future line of action pertaining to sustainable agriculture. It is also useful to prospective local and foreign investors in commercial agriculture and biofuel production to counter balance the opportunities and choices available to them.
\end{abstract}

\section{Key words: Energy; Biofuel; Sustainable agriculture; Nigeria}

\footnotetext{
a The Guardian Editorial Board Rutam House, Isolo, PMB 1217, Oshodi Lagos, Nigeria

*Corresponding author: Luke Onyekakeyah lonyekakeyah@yahoo.com

http://dx.doi.org/10.14453/isngi2013.proc.34
} 


\section{Introduction}

Geographically, Nigeria is located in tropical West Africa approximately between latitudes $5^{0}$ to $15^{0} \mathrm{~N}$ and longitudes $3^{0}$ to $14^{0} \mathrm{E}$. It is the third largest country in Africa after Sudan and Democratic Republic Congo, with a total land area of $923,768 \mathrm{~km}^{2}$. The country shares borders in the east with Cameroon, in the west with Benin Republic, in the north with the Sahara Desert and in the south with the Gulf of Guinea part of the Atlantic Ocean with which it shares $853 \mathrm{~km}$ coastline. In terms of population, Nigeria is the most populous country in Africa and the eight most populous countries in the world with an estimated population of 148 million, according to the 2007 United Nations projections. Economically, Nigeria is a major producer of crude oil. The country is a prominent member of the Organization of Petroleum Exporting Countries (OPEC). She is the largest crude oil producer in Africa and the $6^{\text {th }}$ among the OPEC countries and the $8^{\text {th }}$ largest exporter in the world ${ }^{1}$. Petroleum plays a critical role in the country's economy. Since the dawn of oil boom in the mid 1970s, oil has dominated the entire economic system. About 90 per cent of the country's foreign revenue is derived from crude oil export.

Notwithstanding that the price of oil has soared in the world market over the past three decades with Nigeria earning huge revenue now put at over $\$ 400$ billion since 1960 , the country's economy still remains among the least developed in the world. The country scored 0.470 (low) in the 2007 Human Development Index and was placed at the $158^{\text {th }}$ position in the world. According to the Economist Intelligent Unit and the World Bank, Nigeria's Gross Domestic Product (GDP) at purchasing power parity was only $\$ 170.7$ billion in 2005. The GDP per capita is $\$ 692^{2}$. The poor state of affairs has been attributed to high-level corruption and mismanagement of the country's resources. Unfortunately, this has impacted negatively on practically every sector of the economy. Among other things, Nigeria suffers from severe and chronic energy crisis that has crippled the economy and left the country literally in darkness. Agriculture was abandoned in preference to oil. This has turned the country into a net importer of food while its vast arable land is lying waste.

\section{Agriculture Potential}

Nigeria has great potentials for agricultural development. Over 90 per cent of the country's landmass is arable and could support a wide variety of agricultural products. It is estimated that 82 million hectares out of the country's total land area of about 91 million hectares, or 90 per cent are arable. Unfortunately, only about 34 million hectares, or 41 per cent are under cultivation mostly by peasant farmers. The remaining 48 million hectares of arable land or 59 per cent are lying waste and uncultivated. The climate and soil are conducive for the cultivation of a wide range of crops such as cassava, maize, millet and sorghum. The Food and Agriculture Organization (FAO) classifies the country's soil to have medium to high productivity if properly managed. Peasant farmers cultivate crops in smallholdings using crude implements. The output is grossly low and insufficient for the country's food requirements.

Prior to the oil boom that occurred in the mid 1970s, the country's economy was predominantly agrarian with over 60 per cent of the workforce engaged in peasant farming. Major cash crops such as palm oil, cocoa, rubber, cotton, groundnuts and timber were produced 
for export. Agriculture was the main foreign exchange earner accounting for over 70 per cent in total exports. The shift to oil diseconomy however overturned the agrarian economy and has ever since impacted negatively on agricultural production. Today, the share of agricultural production to total exports has plummeted to mere 2 per cent! Since the 1980s, the growth in agricultural output has not been impressive. For instance, in the first half of the 1980s, which was a period of stagnation in the country, the growth in output averaged just about 0.5 per cent. This was attributed to low producer prices, marketing restrictions and drought. Many farmers abandoned their farm plots in pursuit of other viable economic activities. Some took up white-collar jobs in the cities. Shortly, afterwards, there was a slight improvement in the fortunes of agriculture following some economic reforms introduced in 1986. These included improved producer prices, trade liberalization, dissolution of price fixing marketing boards and the devaluation of the naira.

As a consequence, growth in the sector rose slightly and averaged 3.8 per cent. Many farmers returned to their abandoned fields and there was a burst of activity in cash crop production. The renewed interest however was not sustained. There was little investment in cash crop production, instead, more food crop was produced which contributed to a drastic fall in food importation from 19.3 per cent of total imports in 1983 to 7.1 per cent in 1991 . The government has made effort through giving incentives to encourage farmers to invest in agriculture and agro-based industries but this has not been successful. For instance, the production of cocoa, which is the country's biggest non-oil foreign exchange earner, has remained stagnant at around 160,000 tons per year since 1995. In comparison, the annual average production of cocoa before the oil boom was more than 400,000 tons. The same goes with the other cash crops. The challenge facing the government is in revamping agricultural production and ensuring its sustainability. There is need to shift from subsistence farming to large-scale mechanized agriculture. It is on this basis that we consider investment in large-scale cash crop production for biofuel energy production as important in the quest to revive agriculture.

\section{Energy Crisis}

Nigeria is currently facing a crippling energy crisis. The energy supply is grossly insufficient to meet demand. As a result, the entire country is literally plunged into darkness. This has impacted negatively on socio-economic development goals. The energy output in the country is put at a meager 4000 megawatts (MW) or 4.7 per cent. This amount is generated from all power sources currently in operation. It is generally believed that for the country to grow industrially, the energy generated should be in the neighborhood of 30,000 MW. There is a large gap when this amount is put against what is currently produced.

Nigeria has a wide range of potentially exploitable energy sources. These include hydropower, coal, gas, solar and wind energy. There is also plan to explore nuclear and biofuel energy alternatives. So far, the entire energy need of the country has concentrated on hydropower and gas while the others are left untapped. Unfortunately, both the hydropower and gas have been poorly harnessed. The irrational and lopsided attention given to hydropower and gas are the reasons why the other available sources of energy are not put into the energy plan.

At independence in 1960, there were two electricity-generating bodies in the country. These were the Electricity Corporation of Nigeria (ECN) and the Niger Dams Authority (NDA). The 
two organizations showed great prospects in generating electricity at a time when the economy was predominantly agrarian with low industrial output. In 1972, the two electricity organizations were merged and the National Electric Power Authority (NEPA) was created. Throughout the period, NEPA's performance was anything but good. There was constant epileptic power supply throughout the country, which slowed down economic growth. Many industries folded up due to unreliable power supply. The disgust over NEPA's poor performance reached a crescendo as the economy literally ran on private generating sets that flooded the country. Consequently, in 2006, NEPA was scraped and renamed the Power Holding Company of Nigeria (PHCN), with 18 business units in its stead. The country has a total installed power generating capacity of about 5,000 MW comprising of both hydro and thermal power plants. The 8 main electricitygenerating stations in the country are presented in Table 1.

Owing to official negligence and lack of maintenance, most of the generating plants depreciated and could hardly generate a quarter of their installed capacity. Many packed up and went out of service. In the circumstance, there was need for a total refurbishment to put the plants back on line. This imperative forced government to embark on a rehabilitation plan of some of the ailing power plants as a way of boosting energy output. This involved the replacement and refurbishment of transmission lines and transformers. Between 1999 and 2008 about N7.5 billion $(\$ 62,500,000)$, contract was awarded for the rehabilitation of the 3 units of the Egbin Power Plant of which two of the units, ST4 and ST6 were out of service since 1992. It was planned that the rehabilitation would add at least $660 \mathrm{MW}$ to the $1320 \mathrm{MW}$ plant. Meanwhile, another contract was awarded for the rehabilitation of the premier Kainji Dam. The work involved the complete dismantling of the 8 units of the power plant. It is remarkable that power output in this and the other two dams is affected during the dry season due to low water level. Furthermore, government devised the National Independent Power Plants (NIPP), under which it proposed to build a number of gas-powered stations in different parts of the country. Table 2 presents the proposed independent power projects.

Some state governments also embarked on the development of power plants. The Lagos State Government, for instance, entered into an agreement with Enron Corp of America to build a gaspowered station. The Lagos/Enron power project added 60 megawatts of electricity to the national grid. The Rivers State Government has also completed its own independent power plant. The other states are at various stages of negotiation with their foreign partners to build state owned power plants. It is remarkable that despite this entire attempt, the power sector remains prostrate. The country spent a whopping N16 billion (\$135.5 million) on the power sector in eight years without any visible change or improvement. The crisis in the energy sector provided a fertile ground for graft.

Allegations of corruption, embezzlement and mismanagement of funds have trailed the award of the power contracts by the administration of former president Olusegun Obasanjo. Consequently, the National Assembly decided to probe the entire contracts that were awarded under the independent power projects. Until the issues are sorted out, the Nigerian power sector provides an attraction for prospective foreign investors to take advantage of the huge market that is untapped over the years. 
Table 1: Electricity Generating Stations in Nigeria

\begin{tabular}{|l|l|l|l|l|}
\hline Name & Location & Type & Capacity (MW) & Installation date \\
\hline Ijora & Lagos State & Thermal & 60 & 1956 \\
\hline Kainji & Niger State & Hydropower & 760 & 1968 \\
\hline Ogorode & Lagos State & Thermal & 60 & 1978 \\
\hline Jebba & Kwara State & Hydropower & 540 & 1985 \\
\hline Egbin & Lagos State & Thermal & 1320 & 1987 \\
\hline Shiroro & Niger State & Hydropower & 600 & 1990 \\
\hline Delta VI & Delta State & Thermal & 600 & 1991 \\
\hline Afam & Rivers State & Thermal & NA & NA \\
\hline
\end{tabular}

Table 2: Proposed National Independent Power Plants (NIPP)

\begin{tabular}{|l|l|l|l|}
\hline Name & Location & Type & Capacity (MW) \\
\hline Geregu & Kogi State & Thermal & 414 \\
\hline Omotosho & Ondo State & - do- & 335 \\
\hline Paplanto & Ogun State & - do- & 335 \\
\hline Alaoji & Abia State & - do- & 346 \\
\hline Gbarian & Bayelsa State & - do- & 225 \\
\hline Ihovbor & Edo State & - do- & 451 \\
\hline Egbema & Imo State & - do- & 338 \\
\hline Calabar & Cross River State & - do- & 561 \\
\hline Ibom & Akwa Ibom & - do- & 188 \\
\hline
\end{tabular}

\section{Biofuel Energy Option}

The slow pace of action in realizing the goal of boosting power supply through the independent power plants and the uncertainty surrounding the energy sector formed the basis for looking beyond hydropower and gas for alternative sources of energy. One energy source that is being explored in this regard is biofuel.

Notwithstanding the criticisms against diverting agricultural land to biofuel crop production, government is in the process of developing a framework that would encourage the development of this form of cheap energy to augment what is available. The argument that the development of biofuel would put food out of the reach of the poor is out of the question in Nigeria. While this may be true in some land hungry countries, this is not the case with Nigeria where 48 million hectares or nearly 60 per cent of the country's arable land is lying waste. Nigeria has enough land to grow food crops as well as industrial raw materials for biofuel production. For instance, under the post-independent agrarian economy, large tracts of land were held for the cultivation of export cash crops such a palm oil, cocoa, rubber, timber and cotton without reducing food crop production capacity.

Today, with the abandonment of agriculture, most of the tracts of land used for cash crop production are lying waste. The land is neither used for the production of crops for food nor for industrial raw materials. In the circumstance, it therefore makes more economic sense for the 
country to put the land into crop cultivation for biofuel. Nigerians are desirous of having cheap energy supply irrespective of the source. There is therefore no discontent from the people on the development of biofuel technology in the country. Government on its own is gradually bracing up with the idea of developing biofuel energy technology to reduce the country's energy crisis. In what follows, we shall highlight some of the policy initiatives and actions taken so far by both the government and the private sector towards the development of biofuel in Nigeria.

\section{Policy initiatives and actions}

The Federal Government of Nigeria is currently fashioning out a new energy policy. In June 2007, government approved and issued a gazette on a National Biofuel Policy Incentive (NBPI), which provides the enabling environment for investors to operate. Subsequently, the Nigerian National Petroleum Corporation (NNPC) created a Renewable Energy Division (RED) upon the mandate of government to spearhead the development of the biofuel industry in the country. RED has launched the biofuel initiative by inviting Expressions of Interest (EoI) to enlist core joint-venture (JVs) investors into the industry. The joint venture projects will include investment in large-scale cultivation of sugarcane, cassava ethanol and palm oil biodiesel production. Phase one of the programme includes the launch of four large-scale agricultural ventures as follows:

- A 2x20, 000 hectares sugarcane plantations, fitted with an ethanol, sugar and cogeneration plant.

- A 1x10, 000 hectares cassava farm fitted with an ethanol plant.

- A 1x20, 000 hectares palm oil plantation fitted with oil extraction and biodiesel conversion plant.

The NNPC has accordingly secured appropriate contiguous locations for the projects in parts of the country and has initiated detailed feasibility studies with reputable international experts. The Corporation is seeking to create under the JVs strategic investors with recognized operational expertise in managing the various crops and plants envisaged in the programme. The modalities for the operation and management of the projects are being worked out for the take off of the projects. The Jigawa ethanol project is another programme that government initiated to produce ethanol from sugarcane. These projects are still at the initial stages of completion. They will go into full-scale operation as soon as government works out detailed modalities with its joint venture investors.

A consortium of research organizations, companies and civil society organizations recently announced that it would establish an "AgroTown" ("Biofuel Town") in Nigeria to kick-start a biofuel revolution on the continent. The project which is to be located near Lagos is directly supported by the governments of Brazil and Nigeria. Brazil's President Lula da Silva is a staunch advocate of using biofuel as a vehicle for international cooperation and development assistance. The phase one of the "Biofuel Town" project will comprise of a settlement that would house 1000 bioenergy experts in an area of 6 million square meters. The project is expected to cost US\$100 million. 


\section{Private Sector Intervention}

Global Biofuels Limited, a private venture concern has initiated the construction of Nigeria's first biofuel refinery at Arigidi-Akoko in Ondo State. The refinery is expected to begin operation in July 2009 with a daily production capacity of about 1.5 million liters of ethanol. The plant is reported to have the capacity to employ no fewer than 58, 000 people. Out of this, 8, 000 would gain direct employment, while 50, 000 would be engaged indirectly in the project. The plant would also help Nigeria achieve the mandatory E-10 requirement of the Kyoto Protocol. This requires signatory countries to introduce 10 per cent bio-ethanol with 90 per cent petrol into their market. Obviously, all the effort Nigeria is making is future-oriented. By linking the agricultural sector to biofuel energy, the agricultural potentials of the country would be revolutionized.

\section{Conclusion}

The foregoing sections have highlighted some of the critical issues surrounding the introduction of biofuel into the energy mix in Nigeria. Biofuels are fast gaining credibility and acceptance in many countries particularly in the developed world. The production of biofuels as a substitute for oil and natural gas is actively being pursued by countries focusing on the utilization of cheap organic matter such as cellulose, agricultural and sewage wastes to produce efficiently liquid and gaseous biofuels that yield high heat energy. The only subsisting argument against biofuel production is the perceived diversion of agricultural land and the envisaged food crisis it might generate. Considering Nigeria's poor energy standing and low agricultural productivity, there is need for the country to diversify its energy potentials and invest in mechanized agriculture. Agriculture and biofuel are mutually inclusive and beneficial. Based on the foregoing, it is obvious that embarking on biofuel energy would rekindle interest in farming and boost commercial agriculture. That way, biofuel would have catalyzed sustainable agriculture in the country.

\section{References}

${ }^{1}$ Biopact, Tuesday, May 29, 2007.

${ }^{2}$ The Economist, Nigeria, Folder Profile-Factsheet, 2014, URL: http://www.economist.com/countries/Nigeria/profile.cfm. 